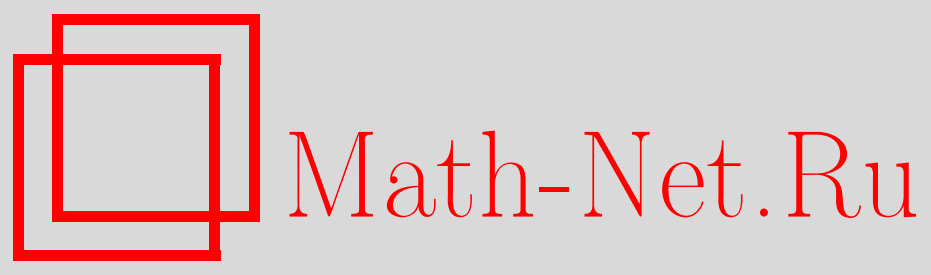

Информационное сообщение о мини-симпозиуме CTCrypt2013, Матем. вопр. криптогр., 2014, том 5, выпуск 2, 5

DOI: https://doi.org/10.4213/mvk111

Использование Общероссийского математического портала Math-Net.Ru подразумевает, что вы прочитали и согласны с пользовательским соглашением http://www . mathnet.ru/rus/agreement

Параметры загрузки:

IP: 107.22 .136 .117

26 апреля 2023 г., 17:38:33

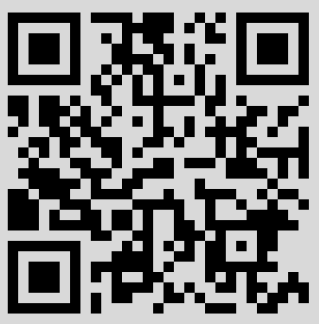




\section{ИНФОРМАЦИОННОЕ СООБЩЕНИЕ \\ о мини-симпозиуме CTCrypt-2013}

23-24 июня 2013 года в Екатеринбурге в рамках 8 Международного симпозиума по компьютерным наукам в России (8th International Computer Science Symposium in Russia, CSR-2013) состоялся минисимпозиум «Современные тенденции в криптографии» (Current Trends in Cryptology, CTCrypt-2013), организованный техническим комитетом по стандартизации TK 26 «Криптографическая защита информации», Академией криптографии Российской Федерации, Математическим институтом им. В.А. Стеклова РАН и Уральским федеральным университетом имени первого Президента России Б. Н. Ельцина при финансовой поддержке ОАО «ИнфоТеКС». Программа мини-симпозиума включала 20 докладов, тематика которых охватывала следующие вопросы:

- исследование конкретных криптографических алгоритмов, в том числе являющихся национальными и международными стандартами (8 докладов);

- математические проблемы криптографии (11 докладов);

- практическая реализация криптографических алгоритмов (1 доклад).

В настоящем выпуске журнала публикуются избранные доклады, сделанные участниками мини-симпозиума. С остальными материалами можно ознакомиться на веб-странице мини-симпозиума http://tc26.ru/CTCrypt/2013/ 